\title{
Articles
}

\section{Capturing the Judiciary from Inside: The Story of Judicial Self- Governance in Slovakia}

\author{
By Samuel Spáč, Katarína Šipulová, ** \& Marína Urbániková***
}

\begin{abstract}
The article discusses the development in the administration of the Slovak judiciary since the separation of Czechoslovakia and the impact of the empowerment of the judicial selfgovernance on the functioning of the judicial system. After independence, the administration of the judiciary initially rested in the hands of the executive. In 2002, Slovakia created its Judicial Council and transferred a considerable amount of powers on it, especially related to judicial careers. It was expected that this would de-politicize the judicial system. However, a high level of autonomy of the judiciary chiefly led to the empowerment of judicial elites. This reduced the democratic accountability of the judiciary, encapsulating it from society and enabling it to promote its own interests. Selection processes have often been used to fill judicial ranks with judges with close ties to the system. Accountability mechanisms such as promotions, disciplinary procedures or remuneration schemes were used to reward allies of those on the top of the hierarchy and to punish their critics. Still, adherence to EU-backed standards on the administration of the judiciary may have increased the legitimacy of the judiciary, while concentrating decisionmaking in one body enhanced transparency, which was furthered due to low public confidence resulting in unprecedented levels of information available about the Slovak judicial system. All in all, the Slovak example displays the dangers of establishing judicial self-governance in countries where an internal ethical culture and a strong sense of judicial duty are still lacking.
\end{abstract}

\footnotetext{
* Samuel Spáč is senior researcher at the Judicial Studies Institute, Masaryk University, and researcher at the Department of Political Science, Comenius University. Email: samuel.spac@law.muni.cz. The research leading to this article has received funding from the European Research Council (ERC) under the European Union's Horizon 2020 research and innovation programme (grant no. 678375- JUDI-ARCH-ERC-2015-STG).

** Katarína Šipulová is senior researcher at the Judicial Studies Institute, Masaryk University, and external advisor in EU law at the Supreme Court of the Czech Republic. Email: katarina.sipulova@law.muni.cz. ORCID: 0000-00023593-3594.

${ }^{* * *}$ Marína Urbániková is senior researcher at the Judicial Studies Institute, Masaryk University, assistant professor at the Faculty of Social Studies, Masaryk University, and the head of research unit at the Office of the Public Defender of Rights of the Czech Republic. Email: m.urbanikova@mail.muni.cz. ORCID: 0000-0003-1640-9823.
} 


\section{A. Introduction}

In less than 30 years since the breakdown of the communist regime, the administration of the Slovak judiciary has gone through a much turbulent development. Starting from a government controlled judiciary in the 1990s, particularly under Prime Minister Vladimír Mečiar, ${ }^{1}$ the political branches enjoyed strong powers vis-à-vis the judicial branch and were not afraid to use them. ${ }^{2}$ In 2001, in compliance with recommendations from the Council of Europe ${ }^{3}$ and the European Commission, which exercised its pressure in the form of the accession conditionality, ${ }^{4}$ Slovakia eventually adopted the 'Euro-model' ${ }^{5}$ of court administration in the form of the Judicial Council, transferring considerable powers to the judiciary, especially in the area of personnel policies. The empowerment of the judiciary took place in a system where the legacies and legal culture of the communist regime have easily survived. ${ }^{6}$ This article examines different models of judicial administration adopted in Slovakia, the reasons behind the major changes, and their effects on the functioning of the judicial system, given the post-communist context. Using the example of Slovakia, the article aims to show that the relationship between the existence of a judicial council and hence the separation of the judiciary from the influence of other branches of power is not

\footnotetext{
${ }^{1}$ There are many labels attached to Mečiar's regime in Slovakia. Classifications differ from so-called "laggards" (Andrew C. Janos, east Central Europe in the Modern World: The Politics of the Borderlands from Pre- to POSTCOMmunism (2000), "troubled democracies" (Herbert KitsChelt, POST-COMmUnist PARTY SYSTems: Competition, RePRESENTATION, AND INTER-PARTY COOPERATION (1999), at 42), and mixed cases (Commission on Security and Cooperation in Europe, Human Rights and Democratization in Slovakia, (1997), Available at: http://www.csce.gov/index.cfm?FuseAction=Files.Download\&FileStore_id=267). See also VALERIE BUNCE AND Sharon Wolchik, Defeating Authoritarian Leaders in Post-Communist Countries (2011). Overall, the literature agrees on the undemocratic character of the Slovak regime up until 1998.

${ }^{2}$ See David Kosař, PerilL of Judicial Self-Government in Transitional Societies (2016), 254-256.

${ }^{3}$ Council of Europe, Committee of Ministers. Recommendation No. R (94) 12 of the Committee of Ministers to member states on the independence, efficiency and role of judges. 13 October 1994, http://www.barobirlik.org.tr/dosyalar/duyurular/hsykkanunteklifi/recR(94)12e.pdf.

${ }^{4}$ European Commission, 2000 Regular Report on Slovakia's Progress towards Accession, November 2000. The suggestions to foster the introduction of proper judicial structures reach as far as to the first progress report from 1998. European Commission. Progress Report on Slovakia, 1998, https://ec.europa.eu/neighbourhoodenlargement/sites/near/files/archives/pdf/key_documents/1998/slovakia_en.pdf.

${ }^{5}$ See Michal Bobek and David Kosař, Global Solutions, Local Damages: A Critical Study in Judicial Councils in Central and Eastern Europe 15 GeRMAN L.J. 1257 (2015); and Kosař, supra note 2, at 126-136.

${ }^{6}$ As Uzelac writes, "socialist legal world was, by its nature, not that socialist" but rather consisted of particular practices, traditions and values. See Alan Uzelac, Survival of the Third Tradition 377 (2010) 49 SUPREME COURT L.R. For more on unsuccessful de-communization of the Slovak judiciary see also Martin Kovanič \& Samuel Spáč, Vyrovnanie sa s minulost'ou $v$ sudcovskom stave, in NEDOTKUNTEL'Ní? POLITIKA SUDCOVSKÝCH KARIÉR NA SLOVENSKU V ROKOCH 1993 - 2015 (Erik Láštic \& Samuel Spáč, eds., 2018). Turnover in the Czech counterpart is estimated to be larger, see Samuel Spáč, Judiciary DeVelopment AFTer the BREAKDown of COMMUNISM IN THE CZECH RePUblic AND SLOVAKIA (MA Thesis, Central European University 2013).
} 
as clear cut as presented by prevailing literature addressing the issue of judicial selfgovernance ("JSG"). ${ }^{7}$

There are several reasons for scepticism about the compatibility of the existing legal culture prevalent in the Slovak judiciary with the requirements placed on democratic judicial systems. Even after almost 30 years since the Velvet Revolution, there are still many judges who were appointed during the communist era. Additionally, the turnover in judicial ranks in the early 1990s was rather marginal, as Slovak political elites refrained from enforcing the Czechoslovak Lustration Law adopted in 1991, ${ }^{8}$ hence even judges appointed after 1989 were socialized and educated in a system deaf to the idea of independence preventing the judiciary from a 'mental' transition to proper democratic values. ${ }^{9}$ This is currently manifested in judges primarily seeing their roles as bureaucrats, ${ }^{10}$ which affects both the application of law and the performance of JSG itself. ${ }^{11}$

Despite the fascinating history of the Slovak JSG, the existing literature on this topic is far from being exhaustive, and it disregards the wider social and cultural background in which JSG interacts with other branches of power. This article fills this gap, and through an indepth analysis of the Judicial Council and other bodies partaking in judicial governance in Slovakia it offers new insights for the study of judicial self-governance and its impact. Furthermore, the article also discusses shifts in the relationship between the judiciary and other branches of government, as well as the implications of these shifts on the core values of the judiciary: independence, legitimacy, accountability, transparency, and public confidence. We opt for a holistic approach: we focus on both the structural setting and the allocation of formal powers, as well as on their translation into practice. It therefore brings novel and important findings for both legal and political science audiences.

The article proceeds as follows: first, section B analyses the rationales of judicial selfgovernment in three stages: The early 1990s; the introduction of a judicial council during the accession to the EU process; and post-accession development. It focuses on the normative and practical changes in judicial independence and accountability. Section $C$ incorporates a more sociological perspective and concentrates on the impact of the JSG on

\footnotetext{
${ }^{7}$ For more see: David Kosař, Beyond Judicial Councils: Forms, Rationales and Impact of Judicial Self-Governance in Europe (in this special issue).

${ }^{8}$ See Kosař, supra note 2 , at 240-243

${ }^{9}$ See Kovanič \& Spáč, supra note 6, at 37-61.

${ }^{10}$ See Michal Bobek, The Fortress of Judicial Independence and the Mental Transitions of the Central European Judiciaries 14 EUROPEAN PUBLIC LAW 99 (2008).

${ }^{11}$ See particularly András Sajó and Vera Losonci, Rule by Law in East Central Europe: Is the Emperor's New Suit a Straightjacket? in CONSTITUTIONALISM AND DEMOCRACY: TRANSITIONS IN THE CONTEMPORARY WORLD 289 (D.Greenberg, ed., 1993), at 322.
} 
the legitimacy of the judiciary, on its transparency towards individual political and societal actors, and public trust and confidence in the judiciary. Section D analyses shifts in the political system and the relationship of the judiciary and JSG bodies towards other branches of power from the separation-of-powers perspective. Finally, Section $\mathrm{E}$ concludes.

\section{B. The Politics of Judicial Independence and Judicial Accountability: from Ministerial Control to Self-Governance and Back?}

As regards the institutional framework of judicial administration, development in Slovakia has been quite turbulent. In this part, we briefly describe the changes in this area, focusing on powers related to the professional careers of judges. ${ }^{12}$ However, we do not focus solely on the institutional setup but also look at how formal powers translate into practice. In other words, in this chapter we focus predominantly on the de jure independence of the judiciary - referring to 'structural insulation' from political branches - and de facto independence, ${ }^{13}$ i.e. execution of these formal powers through the selection of judges, their promotions, or accountability mechanisms. ${ }^{14}$ Additionally, we discuss instances where independence, understood as an output feature of the judicial system, was at stake. ${ }^{15}$ Similarly to independence, we also focus on multiple dimensions of accountability, comparing both the de jure and de facto consequences that the judiciary and individual judges may face in connection to their behavior at the hands of principals in different branches of power. ${ }^{16}$

\footnotetext{
${ }^{12}$ Administrative and managerial powers have to a great extent always belonged to the Ministry of Justice. The Ministry decides about the number of courts, judges, law clerks or other court employees, as well as about the budget of the judicial system, and majority of technical and material equipment. The Ministry also manages all ICT systems used by the courts. The Supreme Court is an exception from this rule as it stands as an independent category in the budget approved by the parliament, however it still uses the same ICT systems, although it administers them on its own.

${ }^{13}$ Various vocabulary has been applied to this dichotomy - it is the difference between independence understood as means and ends, the difference between mechanisms and values, the difference between 'structural insulation' and 'impartiality', or the difference between institutional and decisional independence. For more see e.g.: Stephen B. Burbank and Barry Friedman, Reconsidering Judicial Independence in JUDICIAL INDEPENDENCE AT THE CROSSROADS: AN INTERDISCIPLINARY APPROACH 9 (2002), at 9-42; or Charles G. Geyh, Judicial Independence, Judicial Accountability, and the role of Constitutional Norms in Congressional Regulation of the Courts, 78 INDIANA L.J. 153 (2003), at 153-221; or Shimon Shetreet, Judicial Independence and accountability: core values in liberal democracies in JUdiCIARIES IN COMPARATIVE PERSPECTIVE 3 (H.P.Lee, ed., 2011) at 3-24.

${ }^{14}$ Under the term 'judicial accountability' we include both decisional accountability and behavioral accountability, both on-the-bench and off-the-bench, both formal (e.g. disciplinary proceedings, remuneration) and informal (changing working conditions). For more see Kosař, supra note 2, at 25-120.

${ }^{15}$ See for instance Popova's definition which holds that "independent judiciary delivers decisions that do not consistently reflect preference of a particular group of actors" in Maria Popova, POLITICIZED JUSTICE IN EMERGING DEMOCRACIES: A STUDY OF COURTS IN RUSSIA AND UKRAINE (2012).

${ }^{16}$ See Kosař, supra note 2, at 25-72.
} 
There are three distinguishable periods since the establishment of independent Slovakia in 1993. First, during Mečiar's government, the judiciary was to a large extent controlled by the Ministry of Justice with the help of the parliament. In 1998, when Mečiar's party lost the election to the pro-democratic broad coalition led by Mikuláš Dzurinda, establishing Slovakia as a trustworthy partner for western democracies became the highest priority. In this period, Slovak political elites did what they could to meet the criteria for successful integration, ${ }^{17}$ including a fundamental reform of the judicial system. However, as judicial elites used this strong model of JSG for their own benefit, since 2010 politicians have sought a new arrangement for the administration of judicial careers, with the intention to counterbalance the dominance of judicial actors.

\section{Judiciary Under Political Control (1993 - 1998)}

During the communist regime, the judiciary was almost completely controlled by the ruling party - politicians decided on the appointment, promotion, and dismissal of judges. ${ }^{18}$ Formally, the power was dispersed between the Ministers of Justice, parliaments, ${ }^{19}$ and court presidents, and these actors preserved the power even after the revolution. Perhaps most importantly, judges did not have life tenure and their terms in office rested to a large extent in the hands of politicians. Czechoslovak parliament addressed this issue in 1991, and thereafter judges could be removed from office only as a result of a disciplinary senate decision. Otherwise, the Ministry remained largely in charge.

Slovakia inherited this framework, however the 1992 Constitution re-introduced limited 4year terms for newly appointed judges, while they were appointed by the parliament (National Council of the Slovak Republic, "NCSR") upon the nomination of the Minister of Justice. If judges were re-elected after the 4-year probation period, they enjoyed life tenure. The European Commission repeatedly criticized this provision for the excessive control vested into the hands of political branches ${ }^{20}{ }^{2}$ The European Commission stressed

\footnotetext{
${ }^{17}$ See e.g. European Commission. Progress report on Slovakia 1999, p.14. https://ec.europa.eu/neighbourhoodenlargement/sites/near/files/archives/pdf/key_documents/1999/slovakia_en.pdf. Or European Commission, 2001 Regular Report on Slovakia's progress towards accession, SEC (20010 1475, 13 November 2001, https://ec.europa.eu/neighbourhood-enlargement/sites/near/files/archives/pdf/key_documents/2001/sk_en.pdf

${ }^{18}$ See e.g. Zdeněk Kühn, Socialistická Justice, In KoMUNISTICKÉ PRÁvo (Michal Bobek, Pavel Molek \& Vojtěch Šimíček, eds., 2009); Hakeem O. Yusuf, Calling the Judiciary to Account for the Past: Transitional Justice and Judicial Accountability in Nigeria. 30 LAW \& POlicy 194 (2008); DAVID DYZENHAUS, JUdGING THE JUdGES, JUdGING OURSELVES: TRUth, RECONCILIATION AND THE APARTHEID LEgAL ORDER (2003).

${ }^{19}$ We use plural here as Czechoslovakia was a federal state. Additionally, judges at the lowest level were elected by political representatives at the local level. See Kühn, supra note 18.

${ }^{20}$ The critique also addressed substantive execution of the powers. In 1997, the government refused to nominate 12 judges for re-election without any reasoning. See Kosař, supra note 2, at 256.
} 
the need for and establishment of a judicial council to foster the independence of the judiciary from politicians. $^{21}$

Another problematic aspect of the Slovak system was the strong position of the Ministry towards court presidents, as it was the Minister who appointed and could dismiss court presidents practically at will, ${ }^{22}$ and once again, he did not hesitate to use this power. ${ }^{23}$ The $^{2}$ influence that political branches exercised over court presidents was another major tool of political control over the judiciary. First of all, during the communist regime, court presidents served as 'transmission belts' for political elites towards the judicial system, hence there was a good chance this practice survived in the first decade after the breakdown of the previous regime. ${ }^{24}$ Court presidents controlled the assignment of cases, appointments of chamber presidents or their reassignments within courts and in this way they could secure desirable outcomes in their respective courts. Additionally, they also held crucial powers regarding the accountability of judges - they initiated disciplinary proceedings, and together with the Ministry decided on promotions and secondments of judges. $^{25}$

In this period, there was no evidence of these powers being used either for rewarding allies or punishing critics of judicial or political elites. ${ }^{26}$ This fact is interesting for several reasons, especially considering the tense relationship between the government and judges. $^{27}$ The largest judicial association, the Association of Judges of Slovakia, was occasionally very critical of the government or of the judges who publicly supported some of government's causes. First, it may be argued that the government did not need to resort to these tools, as they exercised sufficient control over the judiciary through appointments and some managerial measures - e.g. the considerable salary hike in the mid-1990s.

\footnotetext{
${ }^{21}$ See for instance European Commission, Agenda 2000, Progress report 1998, Monitoring reports 1999-2000.

${ }^{22}$ The process was a little more complicated regarding the position of the Chief Justice of the Supreme Court, who was elected by the parliament, but the parliament could not dismiss him. However, when in 1997 the Chief Justice Milan Karabin resigned from this position to be replaced by Štefan Harabin, a judge much more closely associated with government parties, it officially happened for health-related reasons, yet Karabin shortly after that continued in his judicial career and eventually became Chief Justice again in 2003. See David Kosař \& Samuel Spáč, Predsedovia súdov: Od ministerských "spojok" k autonómnym aktérom, in NEDOTKUNTEL'Ní? POLITIKA SUDCOVSKÝCH KARIÉR NA SLOVENSKU V ROKOCH 1993 - 2015 (Erik Láštic \& Samuel Spáč, eds., Univerzita Komenského, 2018).

${ }^{23}$ See Kosař, supra note 2, at 256.

${ }^{24}$ See Kosař, supra note 2 , at 49.

${ }^{25}$ See Bobek \& Kosař, supra note 5.

${ }^{26}$ See Kosař, supra note 2, at 338-339.

${ }^{27}$ Minister of Justice Jozef Liščák even referred to some judges as "buggers and frats stupid as cues." See See Kosař, supra note 2 , at 255.
} 
Second, refraining from a more fundamental use of judicial accountability measures may indicate either the government's ambition - possibly a very weak one - to become a standard democratic country, or a lack of courage to strongly oppose democratic forces within the society. Despite its nationalistic rhetoric and use of authoritative methods, the government, in 1995, partially submitted to the European Commission's calls for more autonomy of the judicial branch by establishing judicial boards at the Supreme and regional courts, as well as the Council of Judges of the Slovak Republic. ${ }^{28}$ Nevertheless, although this institution represented the JSG, it was vested only with consultative powers, which the government did not use in practice. ${ }^{29}$ Yet, it deserves to be stressed that judges who criticized the government did not face any extraordinary repercussions. For some of them, especially those representing the Association of Judges of Slovakia, hard times came about a decade later. ${ }^{30}$

II. Empowering Judges: From Euro-Optimism to Disillusion (1998 - 2010)

\section{Euro-Model of Judicial Self-Governance: Changes, Rationales, and Powers}

Parliamentary elections in 1998 marked an important milestone in the history of Slovakia. ${ }^{31}$ The parties of Mečiar's government were replaced by a broad pro-democratic coalition led by Mikuláš Dzurinda. The main goal of this was to catch up with the rest of the Visegrad group and make the country acceptable to Western democracies. It was an era of almost unconditional Euro-optimism, accompanied by numerous reforms, including the reform of judicial administration. First, a new Law on Judges was passed in 2000, securing life tenure for judges, eliminating probation periods, and transferring the appointment competence from the parliament to the President, who acted upon the nomination by the Minister of Justice. A further move towards the 'Euro-model' ${ }^{32}$ of judicial administration took place in 2001 when a Constitutional amendment established the Judicial Council of the Slovak Republic (JCSR), ${ }^{33}$ and the Act on the JCSR passed in the parliament the following year. ${ }^{34}$ In

\footnotetext{
${ }^{28}$ See Kosař, supra note 2, at 255.

${ }^{29}$ In 1997, when the parliament, upon nomination by the Minister, elected Štefan Harabin to become Chief Justice of the Supreme Court, neither the judicial board of the Supreme Court nor the Council favored the appointment. For more see Kosař \& Spáč, supra note 22.

${ }^{30}$ See the following Section.

${ }^{31}$ See Bunce \& Wolchik, supra note 1.

${ }^{32}$ See Bobek \& Kosař, supra note 5; Kosař, supra note 2, at 126-136.

${ }^{33}$ The amendment included a larger bulk of reforms concerning the Constitutional Court, preparing the ground for Slovak accession to the EU, creation of the Supreme Audit Office of the Slovak Republic and reforms regarding regional self-government.

${ }^{34}$ Act No. $185 / 2002$ on the Judicial Council
} 
addition, the Judicial Academy of the Slovak Republic was established in 2003 as an institution fostering the independent education of judges. ${ }^{35}$

The explanatory memorandum for the amendment establishing the JCSR was at times rather vague, referring only to the increase of the quality of democracy, strengthening the independence and autonomy of the judiciary, and 'an honest interest to become a member of the family of European states'. However, parts of the explanatory memorandum specify that the reform was inspired by several international documents namely, UN Basic Principles on the Independence of the Judiciary, Recommendation R (94) 12 of the Committee of Ministers on the Independence, Efficiency and Role of Judges, as well as by the European Charter on the Statute of Judges, and is a response to the critique from observers in the accession process. ${ }^{36}$ The main arguments heard in the debate in favor of the proposal posited that the amendment was necessary if Slovakia wanted to be a member of the European Union, ${ }^{37}$ but the general tone simply suggested that the coalition perceived the adoption of the Council model as the 'right solution', and that it should secure independence, protect the judiciary from the capriciousness of political elites, and even improve the unsatisfactory performance of the judicial system. ${ }^{38}$ Despite the discussion in the parliament, many argue that the adoption of the JCSR was mostly a stance against 'mečiarism' - an autocratic style of government represented by former Prime Minister Vladimír Mečiar - and the EU argument was used to simply legitimize this process. $^{39}$

Originally, the JCSR consisted of eight judges elected by their peers, three members elected by the parliament, three members appointed by the government, and three members appointed by the President of the Slovak Republic, all serving a maximum of two consecutive five-year terms. The last member of the JCSR was its president, who was elected by the other members of the JCSR out of the judges of the Supreme Court, and

\footnotetext{
${ }^{35}$ The idea for such an institution had been promoted by the Association of Judges of Slovakia since 1995, but successfully started its operation only in September 2004. The Academy is governed by a ten-member Board: five nominated by the JCSR from all judges, five nominated by the Minister of Justice, two of them upon the suggestion of the General Prosecutor. Until 2009, at least two members nominated by the Minister had to be judges, thus securing a clear majority for judicial actors.

${ }^{36}$ See Spáč, supra note 6.

${ }^{37}$ See Spáč, supra note 6, at 60-64.

38 See Alexander Bröstl, At the Crossroads on the Way to an Independent Slovak Judiciary in SYSTEMS OF JUSTICE IN TRANSITION: Central AND EASTERn EUROPEAN EXPERIENCES SINCE 1989 (Jiři Přibáň, Pauline Roberts \& James Young, eds., 2003); or Pavol Rohárik, The Judiciary and Its Transition in Slovakia after 1989 in SYSTEMS OF JUSTICE IN TRANSITION: Central AND EAstern EUROPEAN EXPERIENCES SINCE 1989 (Jiři Přibáň, Pauline Roberts \& James Young, eds., 2003).

${ }^{39}$ See Kosař, supra note 2; and Ján Svák, Slovenská skúsenost's optimalizáciou modelu správy súdnictva in HLEDÁNí OPTIMÁLNEHO MODELU SPRÁVY SOUDNICTVÍ PRO ČESKOU REPUBLIKU (J.Kysela, ed., 2008); and Tim Haughton, Exit Choice and Legacy: Explaining Patterns of Party Politics in Post-communist Slovakia"30 EAST EUROPEAN POLITICS 210 (2014).
} 
who at the same time served as the Chief Justice of the Supreme Court. This person therefore enjoyed the dual role of being a very strong actor within the Supreme Court, while at the same time having the power to oversee and influence practically all major decisions in the judicial system. The logic behind the composition was to secure parity between judicial and non-judicial members. Nine judges were supposed to represent the Supreme Court and the eight regional circuits of the Slovak judiciary, ${ }^{40}$ the remaining nine members, nominated by political branches, were supposed to ensure the balance of interests between judges and politicians.

However, as neither the Constitution nor the Law specified that nominees of political branches shall not be judges, ${ }^{41}$ in the JCSR's 15 years of existence, judges have always had a clear majority. ${ }^{42}$ This fact should not be too surprising. Since the introduction of the JCSR, the government, parliamentary majority, as well as the office of the President predominantly belonged to politicians who opposed the adopted composition of this body. The only competing proposal in the parliamentary debate was presented by Štefan Harabin, at that time the Chief Justice of the Supreme Court, who argued for a composition with ten judges and six nominees from the Parliament. Harabin later served as the Minister of Justice (2006-2009), and during his term appointed only judges. Harabin's proposal was backed mainly by the opposition MPs, including Ivan Gašparovič, who served as the President of Slovakia between 2004 and 2014, who filled three out of six positions with judges during his term. Additionally, the proposal was backed by - at that time independent MP Robert Fico, who later became the Prime Minister, serving from 2006 until 14 March 2018, with a 21-month intermission between 2010 and 2012.

\section{Judicial Self-Governance in Practice: Misusing Vested Powers for the Benefit of the Judicial Elite}

The role the JCSR is supposed to play in the political system has never been clear. Most of its powers are related to the professional careers of judges, and our calculation shows that as much as $63 \%$ of almost 3,200 resolutions adopted by the JCSR between 2002 and May 2017 addressed personalmatters. The JCSR has since its establishment been a powerful actor in the appointment, promotion, and secondment of judges, and with considerable powers in disciplining as well as dismissing judges due to their age; although the actual act

\footnotetext{
${ }^{40}$ See Svák, supra note 39.

41 The explanatory note actually included the expectation that political branches will nominate experts in law or representatives of other legal professions.

${ }^{42}$ Between 2002 and 2007 there were twelve judges to six non-judges at the JCSR. Between 2007 and 2012 , the ratio shifted to sixteen judges to two-non-judges. Since then, there have always been at least thirteen judges among the members of the JCSR. All in all, political branches have so far nominated 40 members to the JCSR, 20 of whom were judges.
} 
of dismissal must be carried out by the President, the nomination by the JCSR is necessary. However, what is not clear is whether the JCSR holds a gatekeeper position - i.e. an institution with final say in these matters - or if it is an intermediary that legitimizes decisions made elsewhere. Up until 2011, district courts could select new judges from among the so-called judicial candidates (justiční čakatelia) serving the court. ${ }^{43}$ The JCSR only formally confirmed their nominations by forwarding them to the President for appointment. Similarly, individual court presidents also dealt with promotions and secondments, and the JCSR only 'rubber stamped' their agreements. On the other hand, the JCSR has always decided about the composition and work schedule of disciplinary senates. ${ }^{44}$

Despite the existence of the JCSR, powers regarding the professional careers of judges were dispersed among several actors within the judicial system, with only very few effective checks and balances held by the political branches. For instance, although the character of the court presidents' involvement was considerably different from the communist era and the 1990s, they still remained very powerful. They had a huge informal impact on any development in the judicial system, but also enjoyed a significant say in disciplinary proceedings, as they had the power to initiate them and exercised this power frequently. ${ }^{45}$ This unbalanced setup, based on the illusion that judges were guardians of merit-based decision making who would protect the judiciary from undue pressure, started to crumble shortly after Slovak accession to the EU in 2004.

After the parliamentary elections in 2006, the rightist pro-European government was replaced by a leftist-nationalist government led by Robert Fico, who created a controversial coalition with two parties from Mečiar's 1994-1998 government - the Slovak National Party (SNS), and Mečiar's own Movement for Democratic Slovakia (HZDS). The government appointed Štefan Harabin as the Minister of Justice. Elected in 1997 under

\footnotetext{
${ }^{43}$ This issue was influenced by political conflict regarding the status of 'judicial candidates.' Centre-right governments preferred open selection procedures, leftist and nationalistic parties favored 'judicial candidates' trained and socialized within the system. As a consequence, even before 2011 when selection procedures became obligatory, judges were commonly selected in competitive procedures as positions of 'judicial candidates' were often left vacant by the decision of the Minister of Justice. This was changed in 2008 by the leftist-nationalist government represented by Minister Štefan Harabin, who enacted into law the preference for 'judicial candidates.' For more see: Juraj Palúš, Právna úprava výberu sudcov na Slovensku in PRísTUP K SPRAVOdLIVOSTI BARIÉRY A VÝCHODISKÁ: VÝBER SUDCOV (Kristína Babiaková, ed., 2015).

${ }^{44}$ There are two types of disciplinary senates. In the first instance, the senate consists of three members elected by the JCSR upon nomination by judicial boards, the parliament and the Minister. In the second instance, senates have five members, one nominated by judicial boards, and two nominated by the parliament and the Minister each. Until 2012 there was no requirement to include any non-judges in the senates, hence disciplinary procedures were clearly dominated by judicial actors.

${ }^{45}$ See Kosař, supra note 2 , at $299-332$.
} 
Mečiar's government, he was the former Chief Justice of the Supreme Court and had managed to polarize the judicial system during his term in office. ${ }^{46}$

As Minister, Harabin was not reluctant to utilize his powers. One measure that increased his popularity in the judicial ranks was the re-establishment of 'judicial candidates' as a preferred way of filling vacant judicial positions. This was largely appreciated among the judges, as it gave courts - and its presidents and judicial boards - much more control over the selection of their new colleagues. In 2012, as many as one in five judges had at least one family member working in the judiciary. ${ }^{47}$ He also vastly and purposefully utilized the power to appoint court presidents when during his term 31 out of 54 district court presidents changed, as well as 4 out of 8 presidents of regional courts, hence changing altogether $56 \%$ of presidents of district and regional courts. ${ }^{48}$ Apparently, appointment of court presidents remained of interest for ministers, even though their powers became much more limited. ${ }^{49}$ Additionally, three of these new court presidents were at the time members of the JCSR, two elected by judges, one nominated to the JCSR by Harabin himself. Also, Harabin used his power to temporarily assign judges from different courts to the Ministry of Justice where they participated in the preparation of judicial policies, supporting some judges' perceptions that Harabin was a champion of judges' interests. In the same fashion, Harabin also chose a judge, Daniel Hudák, as his Deputy Minister. Hudák, who was simultaneously Harabin's nominee to the JCSR, was thus both an active representative of the government and a member of the judiciary.

In 2009, while still serving as Minister, Štefan Harabin was elected Chairman of the JCSR and Chief Justice of the Supreme Court, in part by those who were either nominated by him to the JCSR, or by those whom he had promoted in some other way. ${ }^{50}$ Even though the

\footnotetext{
${ }^{46}$ For more about Harabin see Kosaŕ, supra note 2, at 248-254.

47 Gabreil Šipoš, Samuel Spáč \& Peter Klátik. Kto je s kým rodina na našich súdoch; available at: https://transparency.blog.sme.sk/c/342665/Kto-je-s-kym-rodina-na-nasich-sudoch.html

${ }^{48}$ Although previous ministers used this power as well, none of them had done so to a comparable degree as Harabin. Available data show that Minister Ján Čarnogurský $(1998$ - 2002) changed altogether 33\% of court presidents, Daniel Lipšic $(2002$ - 2006) changed $26 \%$ of court presidents, and Lucia Žitňanská (2006) changed $7 \%$ of court presidents. Once Harabin left the office this practice became much more common. Since 2010 there have been two governments with two Ministers of Justice; both of them changed about $50 \%$ of court presidents. For more see Kosař \& Spáč, supra note 22. Among court presidents who were dismissed by Harabin was L'udovít Bradác from the regional court in Banská Bystrica, who was one of most notable representatives of the Association of Judges of Slovakia, which was very critical of Mečiar's government during 1990s.

${ }^{49}$ Most notably, in 2002, court presidents lost their power to assign cases to judges due to the adoption of a system of computerized random assignment. See Katarína Staroňová, Projekt ,Súdny manažment' ako protikorupčný nástroj in JEDENÁSŤ STATOČNÝCH: PRíPADOVÉ ŠTÚDIE PROTIKORUPČNÝCH NÁSTROJOV NA SLOVENSKU (Emília Sičáková Beblavá \& Miroslav Beblavý, eds. 2008).

${ }^{50}$ For more see Kosař \& Spáč, supra note 22.
} 
mechanisms of judicial accountability have produced outcomes that could be labelled as 'accountability perversions' since 1993 - mainly accountability avoidance, simulating judicial accountability or selective accountability $-{ }^{51}$ the situation worsened once Harabin acquired the powers of this dual role. Most prominently, Harabin, with the support of his allies, used his influence to punish his critics through disciplinary procedures. At least fifteen judges were subjected to disciplinary procedures that resembled bullying ${ }^{52}$ or have been described as an 'output perversion of judicial accountability. ${ }^{53}$

One common strategy was to initiate accountability procedures against recalcitrant judges, often for conduct which could have been easily found in the work of his loyal supporters, who either never faced any disciplinary measures or got off with minor sanctions. ${ }^{54}$ Juraj Majchrák was one of the judges who was targeted by these disciplinary procedures. He was a Supreme Court Judge known for his critique of Štefan Harabin ${ }^{55}$ and a prominent representative of the Association of the Judges of Slovakia during the 1990s. He also played an important role in the creation of the JCSR. Majchrák was subjected to three disciplinary proceedings ${ }^{56}$ for delays, which are very common in court operations in Slovakia. As Slovakia ranks among the least efficient judicial systems in the $\mathrm{EU}^{57}$ some delays in proceedings can most likely be found in the work of the vast majority of judges, suggesting that this disciplinary motion selectively targeted Majchrák for openly criticizing Harabin.

Disciplinary motions were not the only accountability mechanism widely used for the benefit of those in power in the judiciary. First, as Chief Justice, Štefan Harabin had the power to award salary bonuses to Supreme Court judges. Especially in 2009, these reached astronomic numbers, when four judges, all members of the JCSR, received bonuses of between 50,000 and 70,000 euros, which effectively more than doubled their annual

\footnotetext{
${ }^{51}$ See Kosaŕ, supra note 2, at 68-72 and 264-332; or Pavol Žilinčík \& Samuel Spáč, Selektívna zúčtovatel'nost': Príklady z disciplinárneho súdnictva, in NEDOTKUNTEĹNí? POLITIKA SUDCOVSKÝCH KARIÉR NA SLOVENSKU V ROKOCH $1993-$ 2015 (Erik Láštic \& Samuel Spáč, eds., Univerzita Komenského 2018).

${ }^{52}$ See LUKASZ BoJARSKI \& WERNER STEMKER KÖSTER, THE SLOVAK JUDICIARY: ITS CURRENT STATE AND CHALLENGES (2012).

${ }^{53}$ See Kosař, supra note 2 , at 68-72.

${ }^{54}$ See Žilinčík \& Spáč, supra note 51.

${ }^{55}$ In 2000, Majchrák, while in position of Vice-president of the Supreme Court, addressed a critical letter to Štefan Harabin, at that time Chief Justice of the Supreme Court, expressing his concerns and disapproval of Harabin's actions in office. See: http://www.sudcovia.sk/sk/dokumenty/1334-otvoreny-list-juraja-majchraka-stefanoviharabinovi-z-8-8-2000

${ }^{56}$ For more information about disciplinary procedures against judges critical of Harabin and his allies see: http://www.sudcovia.sk/sk/dokumenty/disciplinarne-konania/406-14disck-14ot

${ }^{57}$ See e.g. CEPEJ - Council of Europe, European Judicial Systems: Efficiency and Quality of Justice (2016).
} 
salaries. ${ }^{58}$ Second, the use of case-assignment and the re-assignment of judges - especially outside of their original specialization - became increasingly employed strategies used to put pressure on, and hence to control, some judges. This all led to an initiative in 2009 in which 15 judges sent a letter to the main constitutional officials of the country protesting against the use of disciplinary procedures that interfered with the independence of judges. This initiative eventually resulted in the adoption of the Five Sentences statement supported by 105 judges (out of approximately 1,300). ${ }^{59}$

\section{Consequences of Judicial Self-Governance: Broken Promises of the Euro-Model}

The pattern of using power in favor of judges and their personal gains had considerable spillover to the actual decision-making of the courts. The media covered several issues that suggested that courts at times deliver decisions that are consistently in line with some actors' preferences, thus painting a bleak picture of the output independence of the Slovak judiciary. ${ }^{60}$ Štefan Harabin himself was particularly effective in defamation lawsuits against the media and the Office of the General Prosecutor. ${ }^{61}$ There was also a suspicion that the president of the respective district court, a long-time supporter of Harabin, changed the previously random system of case assignment shortly before Harabin filed his lawsuit, which could as a result be assigned only to one of three young judges. ${ }^{62}$ In a similar fashion, several of the famous 'anti-discriminatory' lawsuits filled by 870 judges against the state after the Constitutional Court found the salaries of Special Court ${ }^{63}$ discriminatorily high compared to the rest of the judiciary, ${ }^{64}$ were decided by some of the judges who filled the lawsuit. Finally, there are general concerns among the public on whether the judiciary

\footnotetext{
${ }^{58}$ See Kosař, supra note 2, at 326; ZUZANA ČAPUTOVÁ \& EVA KováČECHOVÁ, PRístup K SPRAVOdLIVOSTI. BARIÉRY A VÝCHODISKÁ. VYBRANÉ ASPEKTY DISCIPLINÁRNÍHO SÚDNICTVA, (2012). Available at: https://viaiuris.sk/wpcontent/uploads/2017/08/pilk-2012.pdf.

${ }^{59}$ This initiative later led to the establishment of a new judicial association called 'For Open Justice'. For more see Bojarski \& Stemker Köster, supra note 52, at 76.

${ }^{60}$ For the definition of judicial independence as a feature of output see Popova, supra note 15.

${ }^{61}$ The General Prosecutor unlawfully confirmed the existence of a recording of Harabin's phone call with an Albanian living in Slovakia, Baki Sadiki, who had in the past been accused of committing drug crimes. This incident has been frequently used against Harabin by his political opponents in the public debate. See: Matúš Burčík, Harabin dostane za potvrdenie telefonátu so Sadikim 150-tisíc eur. SME, November 6, 2013.

${ }^{62}$ In addition, all of these judges were nominated for judgeship in September 2009 by the JCSR, which was at the time led by Štefan Harabin. For more see: Veronika Prušová, Šefka súdu pomohla náhode aj pri pridelení Harabinovej žaloby. SME, May 5, 2013.

${ }^{63}$ For more on the issue of Slovak Specialized Criminal Court see: MATTHEW STEPHENSON, SPECIALIZED ANTI-CORRUPTION COURTS: SLOVAKIA (2016).

${ }^{64}$ Slovak Constitutional Court, judgment of 20 May 2009, PL. ÚS 17/2008.
} 
decides cases independently, ${ }^{65}$ although these concerns may also be related to the perception of widespread political corruption and the impunity of powerful actors.

Figure 1 below portrays the shift in the competences of the actors participating in JSG brought by the introduction of the JCSR. The early 1990s political system understood JSG as a product of the interaction of the triangle of actors: the parliament, the Ministry, and the judiciary. Nevertheless, the concentration of power was clearly in the hands of the executive (Figure 1, black grading), which under the government of PM Mečiar controlled both the parliament and the court presidents (via ministerial nominations). After 1998, the Slovak judiciary gained considerable powers regarding its own administration, particularly those concerned with the professional careers of judges. The year 2002 and the introduction of the JCSR shifted this triangle and almost completely eliminated the influence of the National Council, although, as we will argue later, the impact of the JCSR on the separation of powers and shape of the democratic political system were lacking in the Slovak discussions surrounding the establishment of the Council. Still, the JCSR's introduction shifted the influence and position of individual constitutional actors. Most of the powers are currently concentrated with the JCSR itself. Court presidents are potentially still one of the important stakeholders, although they do not exercise this power.

Figure 1: Competences of judicial governance actors (Source: authors)

$$
\text { 1993-2001 Triangle 2002-2016 Shift }
$$

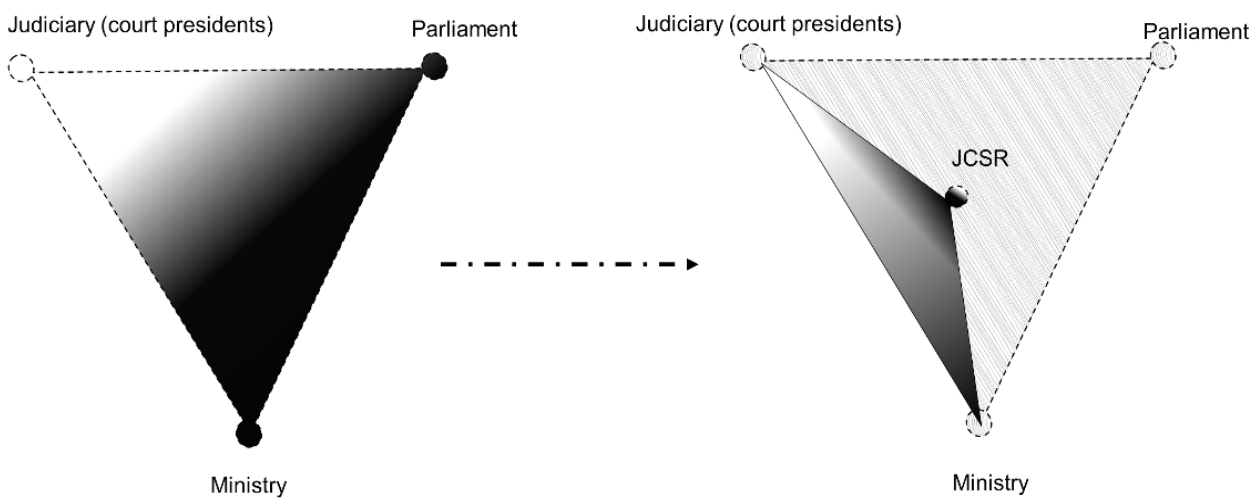

\footnotetext{
${ }^{65}$ For instance, in the Global Corruption Barometer 2013, the judiciary was perceived as the most corrupt institution in Slovakia. Transparency International, GLOBAL CORRUPTION BAROMETER (2013). Also, concerns about independence can be found in Klaus Schwab and Xavier Sala-i-Martín, THE GlobAL COMPETITIVENESS RePORT 20152016 (2016).
} 
However, the Euro-model failed to deliver what was expected. Not only did the JCSR fail to eliminate possible undue influence over the judiciary exercised through the administration of professional careers, but under Harabin's chairmanship, accountability mechanisms suffered even more deficiencies than before and became tools for rewarding his allies and punishing his critics and opponents. These practices, reminiscent of 'mafia-like structures', $^{66}$ led to a deep divide within the judicial branch, while increasing the salience of judicial issues among the public and politicians.

\section{Building (New) Trust between Judges and Politicians? (2010 - 2017)}

Harabin's era in the most powerful position in the Slovak judicial system attracted a lot of attention from unlikely sources. In June 2009, on the day of his election to the post of Chairman of the JCSR, approximately 300 people protested in front of the building where the election was taking place. The demonstration was led by the NGO Fair-Play Alliance and was supported by many judges, lawyers and public figures. ${ }^{67}$ Disciplinary proceedings against Harabin's critics were attended by embassy representatives from some of Slovakia's allies in the EU and NATO. ${ }^{68}$ The 2010 Parliamentary elections brought to power a new coalition led by Iveta Radičová. Its Minister of Justice, Lucia Žitňanská, was clearly determined to limit the power of judges in order to prevent the repetition of past events. This intention remained even when after the breakdown of the government in late 2011, and consequently, after the 2012 elections which led to SMER-SD, a leftist party and main coalition partner of 2006-2010 government, being able to form the government by itself.

The 2011 reform focused on procedures regulating the selection, promotion and discipline of judges and aimed at a considerable increase in the transparency of the judicial branch. ${ }^{69}$ First, as regards the selection of judges, the new law introduced selection through open, competitive and very structured procedures. The committees selecting new judges consisted of at least three judges - two nominated by the JCSR, and one nominated by the judicial board of the court where the procedure was taking place, counterbalanced by two members nominated by political branches, ensuring the dominance of the judiciary. ${ }^{70}$ Despite the introduction of mandatory selection procedures, the process still seemed to

\footnotetext{
${ }^{66}$ See Bobek \& Kosař, supra note 5.

${ }^{67}$ Červená pre Harabina, Pluska, June 10, 2009. Available at: http://www.pluska.sk/old/aktuality/cervena-preharabina.html

68 Veronika Prušová, Harabin: Diplomati si kupujú sudcov darčekmi, SME, May 20, 2010. Available at: https://domov.sme.sk/c/5383790/harabin-diplomati-si-kupuju-sudcov-darcekmi.html

${ }^{69}$ See the following Section and SAMUEL SPÁČ, MATEJ ŠIMALČík \& GABRIEL ŠíPOŠ, LET'S JUDGE THE JUDGES: HOW SLOVAKIA OPENED ITS JUdiciary to UnPRECEDENTED PUBlic CONTROL (2018).

${ }^{70}$ After the reform there were actually three political nominees and two judicial nominees, which was struck down by the Constitutional Court. See Section C.I.
} 
favor candidates with ties to the judiciary - either family relations or connections to people sitting on the selection committees. ${ }^{71}$ As a consequence, in 2017, the new government attempted to restructure the process and fill all vacant district court positions through collective selection procedures organized at the regional courts. New judges are now selected by five-member committees consisting of two members nominated by the JCSR, two members nominated by the Minister, and one member elected by the collegium of judicial boards of the given region.

In 2011, the process of promoting judges to higher courts was transformed in 2011 in a similar fashion. At that time, the composition of the committee was at the time similar, but a change implemented in 2017 meant that the president of the regional court, or the Chief Justice of the Supreme Court would create a five-member committee in which one member is selected from the list created by the JCSR, two are selected from the list crated by the Minister, one is elected by the judicial board of the given court, and one is elected by the collegium in which there is a vacant position.

Changes in the processes of selecting and promoting judges resulted in more involvement of the other branches of power. Somewhat similar logic guided changes related to the composition of disciplinary senates. Since 2012 , there has been an obligation to include non-judicial members to ensure a lay component counterweighing judicial dominance, which had proved to be hazardous in the previous years.

The process of selecting court presidents went through a somewhat similar modification, but in reverse. The executive had held this almost unrestricted competence for years. However, since 2011, court presidents are also selected by five-member committees. As many as three members of the committee are nominated by the Minister of Justice, meaning the executive branch has retained control over the process, but the remaining spots are reserved for one judge nominated by the JCSR, and one by the judicial board of the court.

Finally, a major change regarding the composition of the JCSR - the first and so far only since its establishment - took place in 2014. In order to avoid concentrating too much power in the hands of one actor, the positions of the Chairman of the JCSR and the Chief Justice of the Supreme Court were separated. Consequently, the number of judges elected by judges was raised to nine.

Developments since 2010 in the matter of administering judicial careers show that there was, just as in any other relationship where the trust between partners has been repeatedly trampled, a need to demarcate new boundaries aimed at building trust among

\footnotetext{
${ }^{71}$ For more see: Samuel Spáč, BY THE JUdGES, FoR THE JUdGES: THE STUdY OF JUDICIAL SELECTION IN SLOVAKIA, (Dissertation Thesis, Comenius University, 2017), at 90-125.
} 
actors. These new developments have common themes: adopting new checks and balances into previously existing mechanisms as well as preventing a dangerous concentration of powers, both without compromising the core idea of the judicial administration that has been in place since 2001 - i.e. the dominance of the judicial branch over other branches of government.

Figure 2: Relationship of the JCSR to other institutions and bodies (Source: authors)

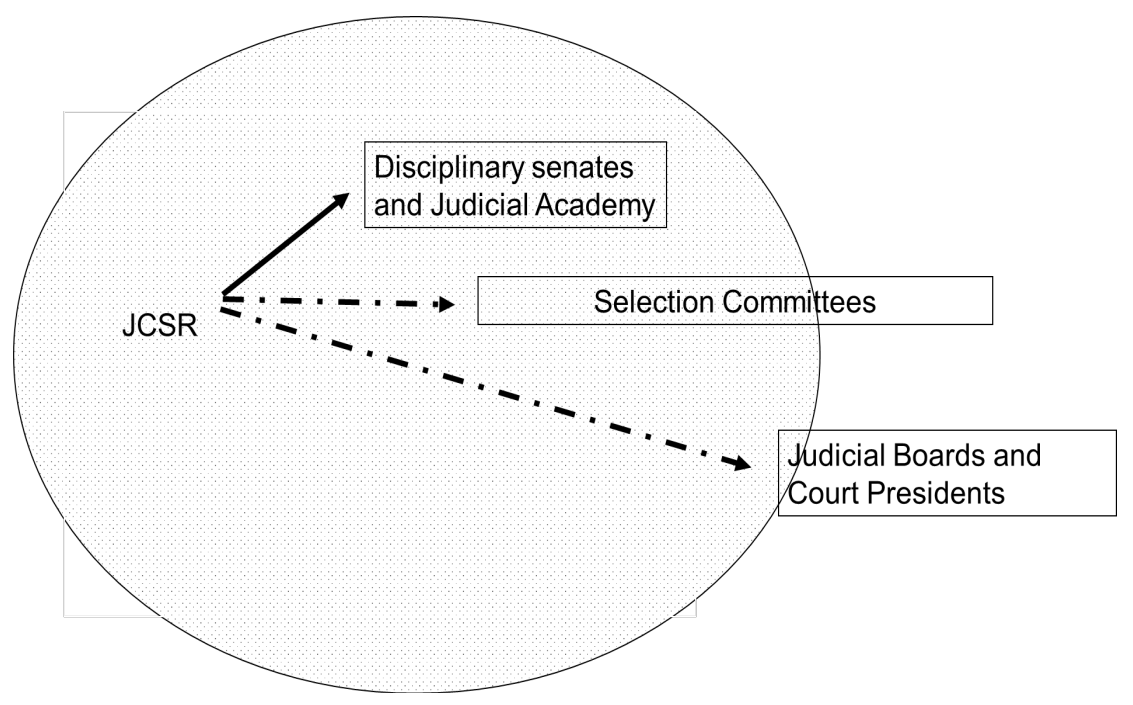

It can therefore be concluded that there are three categories of ties between the JCSR and other bodies taking part in JSG. The first is a group of bodies that are predominantly created by the JCSR and belong under its sphere of influence; this group is represented by the disciplinary senates and the Judicial Academy. The second group is comprised of bodies that are semi-independent of the JCSR; the JCSR has only limited influence in the selection of its members, although it may also act as a gatekeeper. Nevertheless, it rarely uses these competences. The third category represents independent JSG bodies (judicial boards and court presidents), which interact but do not depend on the JCSR.

\section{Judicial Administration and the 'Outside' World: Legitimacy, Public Confidence, and Transparency}

As shown in the previous sections, Slovakia enacted the recommended model of JSG in the form of a strong judicial council with a majority representation of judges. Yet the turbulent political and societal developments in the 1990s justly raise questions of the impact of the JCSR on the judiciary and its position within the political system. This section therefore 
moves from the legalistic and normative historical description of the Slovak JSG model and focuses more on its impact and social acceptance, with specific attention paid to the legitimacy of the judiciary, transparency of the court system and of the judicial administration, and the development of public trust in the judiciary and its relation to changing JSG.

\section{Legal and Normative Legitimacy of the Slovak Judiciary}

The JCSR, as a central institution in the Slovak system of judicial administration, is intended be a body that represents judicial legitimacy, which, together with independence and accountability, belongs among the core elements of judicial systems. ${ }^{72}$ Indeed, it is difficult to untangle what legitimacy actually means. There is a plethora of academic works analyzing different dimensions of legitimacy, ${ }^{73}$ suggesting there is no common understanding of the concept. ${ }^{74}$ In the following part we differentiate between legal legitimacy/legality, ${ }^{75}$ the normative dimension of legitimacy, ${ }^{76}$ and its social dimension. ${ }^{77}$

The legal legitimacy of judicial administration and the bodies conducting it is secured through the entrenchment of all of the core regulations in the Act on Judges and Lay Judges ${ }^{78}$ and the Act on Courts. ${ }^{79}$ Above that stands the JCSR, which is both rooted in the Constitution $^{80}$ and further regulated by the Act on the JCSR. ${ }^{81}$ Additionally, the Constitution

72 On the concept of legitimacy see e.g. James L. Gibson, Gregory A. Caldeira \& Vanessa A. Baird, On the Legitimacy of National High Courts, 92 The American Political SCIence Review 343 (1998), at 343; and W. S. Richards, Survey article: the legitimacy of Supreme Courts in the context of globalization, 4 UTRECHT L.R. 104 (2008), at 104.

73 See e.g. Peter G. Stillman, The Concept of Legitimacy, 7 PoLITY 32 (1974), at 32; and David Beetham, THE LEGITIMATION OF POWER (2013), or Başak Çalı, Anne Koch, Nicola Bruch, The Legitimacy of Human Rights Courts, A Grounded Interpretivist Analysis of the European Court of Human Rights, 35 HUMAN RIGHTS QUARTERLY 955 (2013), at 955 .

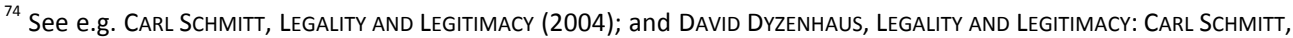
Hans Kelsen And HeRman Heller in Weimar (1999).

75 Supra note 74; and various contributions in: LEGITIMACY IN INTERNATIONAL LAW (Rudiger Wolfrum \& Volker Roben ed. 2008).

76 Allen Buchanan \& Robert Keohane. The Legitimacy of Global Governance Institutions. 20.4 ETHICS \& INTERNATIONAL AFFAIRS 405 (2006).

77 Mark C. Suchman, Managing Legitimacy: Strategic and Institutional Approaches, 20 ACADEMY OF MANAGEMENT REVIEW 571 (1995), at 571.

${ }^{78}$ Act No. $385 / 2000$ Coll.

${ }^{79}$ Act No. $757 / 2004$ Coll.

${ }^{80}$ Art. 141a of the Slovak Constitution

${ }^{81}$ Act No. $185 / 2002$ Coll 
raises the demand that the judiciary be independent and impartial, ${ }^{82}$ however it does not specify the normative meaning of this provision. From this perspective, the normative legitimacy of the existing model of judicial administration is secured in two ways: first, by the set of international recommendations on fostering judicial independence that guided the 2001 Constitutional amendment, ${ }^{83}$ and second, through the Constitutional Court's case law, which clarified the relationship between the formal rules and provisions regulating the JSCR and the principles of judicial independence. ${ }^{84}$

There have been two decisions that interpreted whether the legally enacted model conforms to the ideals of the rule of law, the separation of powers and the judicial independence entrenched in the Constitution. First, in 2014, upon a petition submitted by a group of MPs, the Constitutional Court decided ${ }^{85}$ that the composition of selection committees under the 2011 reform, ${ }^{86}$ which gives a majority to nominees of political branches, breaches the idea of independence. ${ }^{87}$ Additionally, the same decision also declared it unconstitutional for the Minister of Justice to dismiss court presidents at her own discretion - this, as we have shown, was a common practice in past. The Constitutional Court admitted that while the competence of the Minister has a clear basis in the law, it also pointed out the lack of any safeguards against the arbitrary use of this competence.

In a 2015 decision, the Constitutional Court expressed another legitimacy concern when it sided in favor of legislation that held that it was at odds to concurrently serve as both court president (or vice-president) and a member of the JCSR. As court presidents are appointed by the Minister, there were concerns that doubts would be cast on such members due to conflicts of interest. ${ }^{88}$ In both of these decisions, the Constitutional Court justified its decisions with direct references to the JCSR's role of ensuring judicial legitimacy. We can therefore argue that the Constitutional Court protects judicial legitimacy by demarcating the borders of permissible political involvement in the administration of judicial careers.

\footnotetext{
${ }^{82}$ Art. 141 of the Slovak Constitution

${ }^{83}$ See the Section B.2.I.

${ }^{84}$ It needs to be stressed that the Constitutional Court cannot initiate a review, and hence acts only if some other institution files a petition. Within the scope of judicial administration, this power belongs to the JCSR, among other actors.

${ }^{85}$ Slovak Constitutional Court, judgment of 8 May 2014, PL. ÚS 102/2011.

${ }^{86}$ See the Section B.3.

${ }^{87}$ The JCSR, led by Harabin, refused to nominate judges selected by such committees for appointment. After the change in government in 2012, Minister Tomáš Borec sought compromise by nominating, almost exclusively, judges on his 'list' who would eventually be accepted by the JCSR.
}

${ }^{88}$ Slovak Constitutional Court, judgement of November 8, 2015, PL. ÚS 2/2012. 


\section{Wider effects of the JSG: Public Confidence in the Slovak Judiciary}

The establishment of the JCSR and its turbulent, and at times controversial, development also influenced the relationship of the judicial system with the world beyond political institutions, particularly the relationship with the public. One of the most important facets of this relationship is public confidence in the judiciary, which can be described as positive expectations regarding the conduct of judges and courts. ${ }^{89}$

As regards the public's confidence in the Slovak judiciary, the picture has been bleak for years: public confidence in the Slovak justice/legal system constantly belongs among the lowest in the entire European Union. ${ }^{90}$ Figure 3 shows that the level of public distrust in the courts rose markedly between 1997 and $2002^{91}$ and it has remained high ever since, in spite of the introduction of the Judicial Council in 2001. Throughout the last decade, only roughly one-third of Slovak citizens claimed to have trust in the courts. In 2016, the share of distrusting respondents decreased for the first time in a decade. This could be related to the reassignment of those who held top positions of the judiciary, and fewer scandals and affairs involving judges, which led to lower public and media salience of the judiciary as an issue.

\footnotetext{
${ }^{89}$ Roy J. Lewicki, Daniel J. McAllister \& Robert J. Bies Trust and Distrust: New Relationships and Realities, 23 ACADEMy of MANAGEMENT ReVIEW 438 (1998), at 438-58.

${ }^{90}$ Eurobarometer 385. JUSTICE IN THE EU.

${ }^{91}$ Besides other factors, a steep increase of distrust between 1997 and 2002 could be a consequence of the widespread feeling of injustice related to general political atmosphere in the country and its various financial frauds, and even murders, which had not been investigated and their culprits remained unconvicted. So-called Mečiar's amnesties can serve as an example which had the potential to affect overall perception of justice in the society. For more on Mečiar's amnesties, which were eventually scrapped by the parliament in 2017, see for instance Michal Ovádek, "Unrichtiges Recht" in Slovakia? The Radbruch Formula and Positive Law from the Nineties, VerfBlog, February 7, 2017. Available at http://verfassungsblog.de/unrichtiges-recht-in-slovakia-theradbruch-formula-and-positive-law-from-the-nineties/
} 
Figure 3: Public Distrust in Courts in Slovakia, 1997-2016 (in \%) ${ }^{92}$

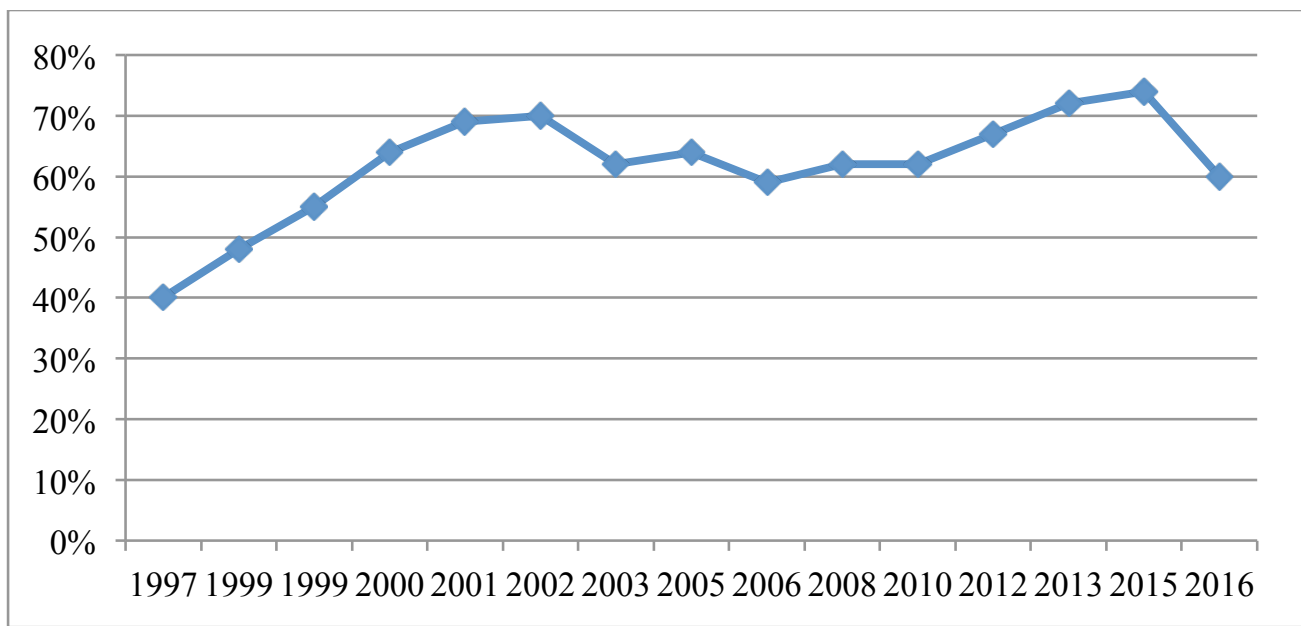

It can be assumed that the main cause of public distrust lies in the perceived lack of independence of courts and judges: only one-fifth of Slovak citizens consider the independence of the judiciary as very or fairly good, ${ }^{93}$ which is the lowest share in the EU. Respondents predominantly stated that interference and pressure from the government and politicians was the main reason for their mistrust. Other factors potentially lowering the level of public confidence are widespread nepotism among the judges, ${ }^{94}$ perceived excessive length of proceedings, ${ }^{95}$ perceived corruption in the judiciary and prosecution, ${ }^{96}$

92 Source: Via luris, Focus 2015 (Via luris, Focus. Vývoj nedôvery v súdy a súdnictvo, roky 1997-2015. https://www.aktuality.sk/foto/305603/5/tri-stvrtiny-slovakov-nedoveruju-sudom-a-dovera-sudnictva-staleklesa/); Via luris 2016 (Via luris. Správa z prieskumu verejnej mienky o dôvere verejnosti $k$ súdom. http://www.viaiuris.sk/wp-content/uploads/2016/10/Spr\%C3\%A1va-z-prieskumu-d\%C3\%B4vera-verejnostivo\%C4\%8Di-s\%C3\%BAdom-2016.pdf). The question asked was: "To what extent do you trust or distrust the courts and the judiciary?" Possible answers: I definitely trust/I rather trust/I rather distrust/I definitely distrust them. Legend: The data in the figure represent the share of respondents who rather + definitely distrust the courts and the judiciary.

${ }^{93}$ The 2016 EU Justice Scoreboard.

${ }^{94}$ According to Transparency International Slovakia, every fifth judge has a close family relationship to another judge or other court employee. See Šipoš, Spáč \& Klátik, supra note 47.

${ }^{95}$ Eurobarometer, supra note 90. According to the 2016 EU Justice Scoreboard, the estimated time needed to resolve a case in court (meaning the time taken by the court to reach an initial decision) was 238 days in Slovakia, only slightly above the average of 225 days calculated for 21 EU countries.

${ }^{96}$ FOCUS. Percepcia korupcie na Slovensku. Prieskum verejnej mienky pre Transparency International Slovensko (2015). Available at: http://www.transparency.sk/wp-content/uploads/2015/05/FOCUS-Percepcia-korupcie-naSlovensku-feb.2015.pdf 
perceived lack of fairness of judgements, ${ }^{97}$ and perceived low intelligibility of judicial decisions. ${ }^{98}$ From this perspective, it must be concluded that a strong JSG has been unable to significantly improve the performance of the Slovak judiciary, or at least its public image. On the other hand, the credibility of courts and judges has been further damaged by their numerous scandals and affairs, ${ }^{99}$ often involving those in top positions, most prominently the previously-mentioned Štefan Harabin. ${ }^{100}$

Thus, to put it bluntly, Slovakia can serve as definite proof that the mere transfer of power into the hands of judges (e.g. via the establishment of a judicial council) does not automatically lead to higher public confidence in courts and the judiciary. On the contrary, when the judiciary is represented and governed by judges who do not inspire trust, and when these top representatives instead cause scandals and affairs rather than help to set them right, the strong model of JSG can lead to the corrosion of public confidence in the judiciary.

\section{Transparency of the Slovak Judiciary}

The low level of public confidence accompanied by problems such as perceived corruption and nepotism were the main reasons why the 2011 reform saw a considerable increase in transparency of the judicial system and the processes related to judges and their professional careers. ${ }^{101}$ Prior to this, a major improvement in transparency of the Slovak judiciary emerged with the establishment of the JCSR. Since 2003, the JCSR has published documents regarding its operation on its website, however for years this has only included the publication of resolutions adopted by the JCSR, without any information about its meetings. Also, the JCSR has, practically since its establishment, published anonymized decisions of disciplinary senates on its website.

\footnotetext{
${ }^{97}$ Eurobarometer, supra note 90.

${ }^{98}$ Eurobarometer, supra note 90.

${ }^{99}$ E.g. in the so-called Bonanno affair, four judges of the Supreme Court sued the tabloid Nový Čas for publishing pictures from their private party held in 2011. The pictures captured their host welcoming them with a submachine gun and blue ear-protectors, imitating the mass murderer who shot dead seven persons in Bratislava two months earlier. In 2017, the Constitutional Court overturned the decisions of district and regional courts and stated that the daily does not need to apologize nor pay any compensation.

${ }^{100}$ See Section B.II.2. For instance, the media published the transcripts of Harabin's intimate 1994 conversation with an Albanian drug mafia boss, and a former attorney general indirectly confirmed its authenticity (Harabin later sue him for doing so). Among other scandals, he repeatedly publicly insulted other judges or members of Judicial Councils (e.g. calling them "juristutes"), and has several times been accused of bullying judges and attempting to influence their verdicts. See, e.g. Martin M. ŠIMEČKA, The Crooked Judges of Slovakia. RESPEKT, November 20, 2012. Available at: https://www.respekt.cz/respekt-in-english/the-crooked-judges-of-slovakia.
}

${ }^{101}$ For a more detailed discussion of changes see SPÁč, ŠIMALČík \& Š́́POš, supra note 69. 
Since this reform, the JCSR publishes minutes from each meeting together with their audio recordings. Before any meeting, all discussed documents need to be published as well. The JCSR is also responsible for publishing the asset disclosures of all judges, which includes a list of a judge's family members working in the judicial system or in organizations in the Ministry's portfolio, e.g. state penitentiaries.

In addition, since the reform, courts are obliged to publish all their final decisions online within 15 days after they come into force. Similarly, courts publish information about all scheduled hearings, including dates, times, as well as the names of parties in criminal and administrative cases. ${ }^{102}$ Furthermore, as regards the day-to-day operations of the courts, each court is obliged to publish its work schedules and all of their amendments. ${ }^{103}$ All this information is published on the Ministry's website; the only exception is the Supreme Court, which publishes its decisions separately on its own website. Courts are also obliged to publish two types of information about individual judges or candidates for judicial positions. First, 'annual statistical reports' include descriptive information about the performance of each judge, such as the number of assigned and resolved cases in a given period, as well as information about a judge's docket, or how a higher court had decided on appeals to their decisions. From a transparency perspective it needs to be stressed that they are difficult to understand and are not necessarily helpful, either for better understanding the system or in holding it accountable. ${ }^{104}$ Courts are also obliged to publish detailed information about selection procedures for all judicial positions including the résumés of all candidates, their motivation letters, candidates' disclosures about family ties in the judiciary, as well as detailed reports from these procedures. ${ }^{105}$

All in all, the effects of establishing a strong JSG in Slovakia are rather mixed. On one hand, the legal legitimacy of the judicial system is secured by the entrenchment of all institutions playing a role in administration, either in the Constitution or in laws, while its normative content is protected by the Constitutional Court. Rather recently, this problem has also been addressed by a considerable increase in the transparency of the system, however its effect cannot be assessed with confidence at this point.

\footnotetext{
${ }^{102}$ This fact effectively de-anonymizes decisions, which themselves are made anonymous. It possibly raises a concern about the conflict between transparency and protection of privacy.

${ }^{103}$ Work schedules contain information about the composition of senates, rules of case assignment or time-slots allocated for the hearings of each judge.

${ }^{104}$ So far, there has only been one attempt to make sense of this data. See: Samuel Spáč, Judging the Judges: Measuring Performance of District Court Judges in Slovakia (2015) (unpublished manuscript, available at: https://www.researchgate.net/publication/285589433_Judging_the_Judges_Measuring_Performance_of_District _Court_Judges_in_Slovakia).

${ }^{105}$ For more see Spáč, supra note 71, at 90-125.
} 


\section{Discussion: Slovak Judicial Administration in the Context of Separation of Powers Theories}

\section{Repercussions of Judicial Self-Government for the Principle of Separation of Powers}

Despite expectations that the establishment of judicial councils should help insulate the judiciary from undue influence, the previous sections showed that there are limits to such assumptions. On one hand it is true that a greater level of JSG helped to insulate the judiciary from direct political pressure. On the other hand, it allowed for an unexpected capture of the judiciary 'from inside' through rewarding the allies of those in power and punishing their critics. These repercussions point at the drawbacks and limits inherently tied with the establishment of strong judicial councils in post-authoritarian, transitioning countries.

The mere idea of introducing the JCSR in 2002 was to shift the creative power from the executive to an autonomous body, the JCSR, which newly gained wide discretion and competence to decide on the appointment of new judges, promotion of judges, appointments of disciplinary senates, etc. ${ }^{106}$ The JCSR, an independent body widely recommended by international bodies and observers, was believed to help insulate the Slovak judiciary from undue political pressure. The main legislative amendments, targeting the division of competences between the Minister of Justice, court presidents, and the JCSR, therefore directly addressed the 'checks and balances' aspect of the separation of powers principle, ${ }^{107}$ while other elements of the division of powers principle, such as the separation of institutions, separation of functions, and personal incompatibility did not really come into play. ${ }^{108}$ Similarly, the question of democratic deficit was never raised in the discussion. It seems that Slovak stakeholders perceived the establishment of a judicial council as a panacea for the mishaps of the previous Mečiar government in the judiciary and one of the leverages that would help the country achieve an ideal, western type, democratic political system. Hence the recommendations of the European Commission, which strongly suggested that Slovakia should establish a judicial council, did not raise questions of whether this institution suited the political and judicial environment or what impact would it have.

Strikingly, while the Slovak political system completely ignores the problem of "travelling institutionaries", a phenomena strongly present in the Slovak political culture and judiciary, it almost obsessively adheres to checks and balances. Between two terms in the

\footnotetext{
${ }^{106}$ For more detail, see Section B.II.

${ }^{107}$ See Jeremy Waldron, Separation of Powers in Thought and Practice?, 54 BOSTON COLLEGE L.R. 433 (2013), at 433; and Christoph Möllers, The Three Branches: A Comparative Model SeParation of PoWers (2013).

${ }^{108}$ See Waldron, supra note 106; or Möllers, supra note 107.
} 
office of Chief Justice of the Supreme Court and the President of the JCSR, Štefan Harabin managed to serve for three years as Minister of Justice, effectively moving from one branch to another and back. Additionally, he was not the only judge who eventually returned to the judiciary who also served as the Minister of Justice. The same applies to Harabin's successor Viera Petríková, who moved from a small district court to the governmental position only to be later promoted to the Supreme Court. Further, there were two judges who have served as Deputy Ministers without ever resigning from their judicial office. Daniel Hudák was Deputy Minister during Harabin's and Petríková's terms between 2006 and 2010, and after that moved back to the judiciary. Monika Jakovská has served under two Ministers since 2012 until the present day, and is still officially listed as a judge. Jankovská was even included on the party list of SMER-SD in the 2016 parliamentary elections, and Supreme Court Judge Peter Paluda ran for office in the 2012 parliamentary elections.

On the contrary, the process of selecting judges perfectly illustrates an almost comical obsession with checks and balances. As many as four different bodies are involved in the process of appointment to a judicial office. First, a selection committee consisting of both judicial and political nominees tests a candidate's competence to perform in the judiciary. Second, the National Security Agency ${ }^{109}$ vets the candidate's background and ability to act independently and impartially. Third, the JCSR, also a body with representatives of both the judiciary and political branches, decides on nomination for the appointment. And finally, a candidate assumes the office only after appointment by the president.

It is however worth noting the historical and socio-cultural background under which the checks and balances principle represent an integral and important part of Slovakia's early political development. The power struggle between Mečiar and his political opponents in the early transitioning era of 1993-1998 represented a core of the Slovak Constitutional Court's case law even prior to the introduction of the JCSR. The Slovak Constitutional Court, under the gradual shift to semi-authoritarianism, was typically petitioned with cases regarding (1) interference with the independence of the NCSR (attempts to remove unwanted designated deputies from their offices), ${ }^{110}$ and (2) disputes and conflicts between the President and PM Mečiar regarding the continual interference of the government in what should have been presidential competences. It is worth noting that in the 1994-1998 electoral term, the Slovak Constitutional Court typically acted as the President's ally, while President Kováč often used the Constitutional Court as leverage

\footnotetext{
109 The requirement that the Agency provides security clearances of all new judges was introduced in the Constitutional amendment in 2014 in Art. 154d of the Slovak Constitution. For more see Erik Láštic and Samuel Spáč, Slovakia / Slovaquie 26 EUROPEAN REVIEW OF PUBLIC LAW 1209 (2014).

110 See Slovak Constitutional Court, judgement of June 2, 1993, I. ÚS 39/93; or Slovak Constitutional Court, judgement of November 29, 1995, PL. ÚS 29/95; or Slovak Constitutional Court, judgement of July 11, 1996, I. ÚS $7 / 96$.
} 
against Mečiar. The atmosphere of constant power struggles, lack of clear institutional boundaries, and strong anti-Mečiar sentiments created a pressing need to anchor constitutional institutions, set the boundaries of their power, and secure an independent judiciary. Some competence disputes continued to appear before the Constitutional Court as late as in the 2010s, especially during government attempts to remove some Judicial Council members with close ties to Mečiar's regime from office. ${ }^{111}$ Another huge cluster of cases regarded the refusal of President Gašparovič to nominate new Constitutional Court judges, although they had already been approved by the parliament. ${ }^{112}$

\section{JCSR and the Politicization of the Slovak Judiciary}

While the Constitutional Court represented an influential actor in the separation of powers (mostly checks and balances) principle and policies, the introduction of the JCSR paradoxically reduced its influence. As a body established by the Constitution, the Constitutional Court had to treat it as a constitutional authority, and therefore with much more constraint when it came to the review of JCSR's actions.

When we attempt to answer the question whether the JCSR itself managed to depoliticize the Slovak judiciary, the results are, at best, dubious. It is however crucial to understand the broader political context and atmosphere in which the JCSR was operating. First, the standing judges and especially the incumbent Chief Justice of the Supreme Court, Harabin, allied with Mečiar, stretched and complicated the process of establishing the JCSR as much as possible. Second, the period of calm under the new chairmanship of Milan Karabín in 2003 was short lived. The parliamentary elections of 2006 returned Mečiar to the governing coalition, whose Prime Minister Fico allowed Harabin to become the Minister of Justice. At this point, Harabin changed his strategy of being critical of the JCSR and started preparing the ground to cement his own influence in the judiciary by entering the JCSR as its president. As the Minister of Justice, Harabin therefore supported the wide discretion and broadening of the JCSR's competences. This idea was initially supported by Fico's government, which was a strong proponent of JSG. Harabin was able to hand-pick JCSR members both for the government and legislature, maintained sufficient support among judges thanks to his carrots and sticks policy (rewarding allies and punishing critics), orchestrated his own comeback and appointment as the future Chief Justice of the Supreme Court, and hence, as the JCSR chairman. Harabin's initial popularity was built on strong ties among judges in Eastern Slovakia and, paradoxically, a rhetoric of an independent judiciary in which judges know best how to govern and regulate the system.

\footnotetext{
${ }^{111}$ Especially the removal of Harabin from the presidential post in the JCSR. See Slovak Constitutional Court, resolution of February, 17 2011, IV. ÚS 46/2011.

${ }^{112}$ Ref. Here, SCC was heavily inspired by the case law of the Czech Constitutional Court, to the extent that the Chief Justice informally approached the CCC asking for a solution which CCC had implemented in past, when faced with President Klaus's refusal of to nominate new judges.
} 
The political salience of the topic and the level of governmental inference, nevertheless, did not cease completely after the change of government in the 2010 election. On the contrary, the new Minister of Justice, Žitňanská, entered into an open war with Harabin over a series of attempted reforms, and the new SMER government continued in these efforts during 2012-2016. Interestingly, Harabin was eventually becoming more and more toxic and finally, the entire political sphere stood united in the view that Harabin should be removed. This happened in 2014, when the JCSR elected a new Chief Justice of the Supreme Court as well as President of the JCSR.

\section{E. Conclusion: JCSR and the Position of the Slovak Judiciary within the Political System}

As shown in the previous sections, Slovakia, in the atmosphere of post-Mečiar optimistic Europeanization and under the political pressure of the European Commission and the Council of Europe, adopted the recommended model of judicial council with the predominant influence of judges. The introduction of the judicial council significantly shifted the picture and the competences of bodies (and the representation of other branches of power) on the JSG, with the JCSR clearly being the most powerful and influential actor. Compared with pre-2002, the influence of other branches of power was significantly diminished, especially for the parliament. Although the court presidents still hold strong competences, they rarely act on them.

This article demonstrated that the influence of such a strong model of judicial council and the separation of the judiciary from the influence of other political branches is not clear cut. The article aimed to address both structural changes in judicial self-governance and their relationship to five core values inherent to the judiciary: independence, accountability, legitimacy, transparency, and public confidence and the trust in courts. Based on an in-depth analysis, we can conclude that the association between the establishment of the JCSR and potential improvement in these values is, at best, dubious. While formally, several mechanisms and competences fostering the independence and accountability of judiciary were introduced, their effect was diminished by continuing political struggles surrounding the JCSR. Moreover, the Constitutional Court often a played much more important role in protecting these principles than the JCSR itself. The overall level of distrust in the courts rose significantly between 1997 and 2002, and has remained very high until now. The introduction of the JCSR has not helped to lessen it.

Finally, the effect of the JSCR on the position of the Slovak judiciary within the separation of powers principle was twofold. First, the wide discretion and most of the JSG competences were vested in the JCSR, which is, for the most part, truly independent of the government and the Ministry of Justice. Judges have particularly strong influence over selection, promotion, and disciplinary procedures. Moreover, the JCSR is more or less controlled by judges, with most of its members hand-picked in the last appointment round 
by the Association of Judges of Slovakia. With the help of politicians, the JCSR was hijacked by judges who used their powers to capture the judiciary from inside, and they have used their powers in such a manner that helps them to protect their interests. 